\title{
Genetic Divergence Studies in Cucumber (Cucumis sativus L.) Genotypes for Yield and Quality
}

\author{
J. Phani kumar ${ }^{1 *}$, Sadarunnisa Syed ${ }^{2}$, P. Syam Sundar Reddy ${ }^{3}$, L. Mukunda Lakshmi ${ }^{4}$ \\ and D. Srinivasa Reddy ${ }^{5}$ \\ College of Horticulture, Anantharajupeta, Dr.YSR Horticultural University, \\ Venkataramannagudem-516105, India \\ *Corresponding author
}

\begin{tabular}{|l|}
\hline Ke y w o r d s \\
Cucumber \\
genotypes, Genetic \\
variability, \\
Heritability
\end{tabular}

\section{Introduction}

Cucumber, Cucumis sativus L. $(2 \mathrm{n}=14)$ is one of the most important cucurbitaceous

\begin{abstract}
A B S T R A C T
The present study was carried out during Late kharif, 2016 at College of Horticulture, Anantharajupeta. The experiment was conducted with an objective to identify divergent genotypes to be used as donor parents in crop improvement. Thirty-two genotypes along with two checks were evaluated in a randomized block design with three replications and the data on 25 yield and yield attributing traits were recorded. The analysis of variance revealed significant differences among all genotypes indicating the presence of sufficient amount of variability for the characters studied. Wide range of variability was observed for number of fruits per plant, fruit weight, fruit yield per plant, powdery mildew incidence and aphid infestation, indicating the scope for selection of suitable initial breeding material for further breeding programme. The genotypes belong to the clusters VI and III, when the $\mathrm{D}^{2}$ analysis was carried out for 24 characters which partitioned the thirty-two genotypes into 6 clusters, which are genetically divergent and hybridization between these genotypes will likely produce desirable segregants. The characters like primary branches per plant, days to first male flowering, days to first female flowering, days to $50 \%$ male flowering, days to $50 \%$ female flowering, days to first fruit harvest, days to last harvest, number of seeds per fruit, TSS, carotenoids, acidity, ascorbic acid and fruit yield per vine recorded high heritability in conjunction with high genetic advance as percent of mean, suggests the predominant role of additive genetic component in governing of these traits and improvement of these traits through simple selection can be employed in cucumber. The genotypes exhibited high variability for most of the traits like plant growth characters, fruit characters, quality and seed characters. On the basis of mean performance of the genotypes studied, in terms of earliness, yield and quality traits, the genotypes viz., A10 (JS 541367), A12 (JB 595504), A22 (IC 321367) and A30 (IC 550207) were found superior and were identified as promising lines for further crop improvement in cucumber.
\end{abstract}

vegetable crops grown widely in tropical and sub-tropical parts of the world, which is native to the Indian subcontinent (Sebastian et al., 2010). Cucumber is a warm season crop which 
is grown extensively throughout the year in southern states of India. In plains of northern India, it is grown in summer and rainy season, but it does not tolerate cold injury (Rastogi, 1998). In the recent past, cucumber has shown tremendous potential and has gained importance as a high value vegetable crop under protected cultivation. It is highly crosspollinated crop and usually monoecious in nature. Other sex forms viz., androecious, gynoecious, hermaphrodite and andromonoecious can be encountered in cucumber (Bailey, 1969).

The scope of improvement of any crop depends upon the magnitude of genetic variability present in the available germplasm. Greater the variability in the available germplasm, better would be the chances of selecting superior genotypes (Simmonds, 1962). In cucumber too, fruits vary in shape, size, colour, maturity and taste. Before starting any breeding programme, genetic variability must be available in the parental material. Further, phenotypic variability being controlled by environmental factors may not prove effective in crop improvement. Therefore, it is necessary to partition the phenotypic variations into its genetic and environmental components, because in the total variability, not only the heritable genetic components but also genetic advance is important, as it predicts the extent of advancement to next generation through selection.

While selecting for yield, one should take into account the improvement of yield contributing traits, provided that the association of such traits with yield is known. Moreover, correlation and path coefficient analysis have been of immense help in selecting suitable plant type. So, in order to identify the desirable genotypes, there is an urgent need to assess the existing variability for higher yield and quality under specific conditions. Hence, the present investigation was chosen to evaluate the genotypes for better parent for hybridization programme.

\section{Materials and Methods}

The present investigation was carried out during Late kharif, 2016 at College of Horticulture, Anantharajupeta, Dr. Y.S.R. Horticultural University, Andhra Pradesh. This location is at an elevation of $162 \mathrm{~m}$ (531 feet) above mean sea level lying between the $13^{0} 59^{\prime}$ North latitude and $79^{0} 19^{\prime}$ East longitude. The total rainfall during growing season was $255 \mathrm{~mm}$. The maximum and minimum temperatures ranged from $28.14^{\circ} \mathrm{C}$ to $35.71^{\circ} \mathrm{C}$ and $18.57{ }^{0} \mathrm{C}$ to $27.57^{\circ} \mathrm{C}$ respectively. The relative humidity during the period of crop growth ranged between 33.14 to $99.71 \%$.

\section{Planting material}

The experiment was laid-out under a shade net in a randomized block design replicated thrice. In each replication, each genotype was grown in a single row of $6 \mathrm{~m}$ length with a spacing of $75 \times 60 \mathrm{~cm}$ accommodating 10 plants in a replication. The experimental material (Table. 1) comprised of a set of 32 genotypes (30 accessions and 2 checks). Thirty genotypes were obtained from NBPGR, Regional Station, Thrissur and Jodhpur. Two genotypes viz., Multistar RZ F1 and ICPCHI served as checks.

The recommended fertilizer dose of $\mathrm{N}$ : $\mathrm{P}_{2} \mathrm{O}_{5}: \mathrm{K}_{2} \mathrm{O}$ was applied at the time of field preparation at the rate of 400,315 and $100 \mathrm{Kg}$ $\mathrm{ha}^{-1}$ as calcium ammonium nitrate, single superphosphate, and muriate of potash, respectively. Seeds were sown in protrays initially, there after transplanted to beds on $15^{\text {th }}$ day. Observations were recorded on vine length, No. of primary branches per plant, inter nodal length, No. of nodes per vine, node 
number at which first female flower appearance, days to first male \& female flowering, days to $50 \%$ male \& female flowering, days to first \& last fruit harvest, fruit length, diameter, weight, No. of seeds per fruit, 100 seed weight, TSS, Carotenoid content, acidity, ascorbic acid, yield per plant, powdery mildew \& aphid incidence in 10 random plants per treatment.

Grouping of the genotypes into different clusters was done by using Torcher's method as described by Rao (1952). The criterion used in clustering by this method is that any two variables belonging to the same cluster should at least on an average show a smaller $\mathrm{D}^{2}$ value among themselves than those belonging to two different clusters. For this purpose, $\mathrm{D}^{2}$ values of all the possible combinations in each genotype was arranged in increasing order of the magnitude in a tabular form as described by Singh and Choudhary (1985).

\section{Statistical analysis}

Genotypic coefficient of variation (GCV), phenotypic coefficient of variation (PCV), broad sense heritability, genetic advance and genetic gain were computed as per standard formulas.

\section{Analysis of variance}

The data for different characters were statistically analysed on the basis of the model described by Panse and Sukhatme (1961).

$Y i j=u+g i+r j+e i j$

Where,

Yji $=$ Phenotypic observation in $i^{\text {th }}$ genotype and $\mathrm{j}^{\text {th }}$ replication, $\mathrm{u}=$ General mean

gi= Effect of $i^{\text {th }}$ genotype

$r j=$ Effect of $j^{\text {th }}$ replication

ejj $=$ Random error associated with $i^{\text {th }}$ genotype and $\mathrm{j}^{\text {th }}$ replication.

\section{Genetic variance}

It is the variance contributed by genetic causes or the genetic occurrence of difference among the individuals due to their genetic makeup. It was calculated by using the formula given by Al-Jibouri, 1958.

$\mathrm{Vg}=\frac{\mathrm{MSV}-\mathrm{V}_{\mathrm{3}}}{\mathrm{r}}=\frac{\mathrm{b}^{\prime}-\mathrm{c}^{\prime}}{\mathrm{r}}$

Where,

$\mathrm{Vg}=$ Genotypic variance,

$\mathrm{MSV}=$ Mean square for varieties,

$\mathrm{VE}=$ Error mean square and

$r=$ Number of replication

\section{Phenotypic variance}

It is the sum of variance contributed by genetic causes and environmental factors and was computed as formula given by Al-Jibouri, 1958.

$\mathrm{Vp}=\mathrm{Vg}+\mathrm{Ve}$

Where,

$\mathrm{Vp}=$ Phenotypic variance, $\mathrm{Vg}=$ Genotypic variance and $\mathrm{Ve}=$ Error variance.

\section{Genotypic coefficient of variation (GCV)}

The magnitude of genetic variation existing in a character was estimated by the formula given by Burton (1952).

$\mathrm{GCV}=\frac{\sqrt{\mathrm{Vg}}}{\overline{\mathrm{x}}} \mathrm{X} 100$

Where,

$\mathrm{Vg}=$ Genotypic variance and

$\bar{x}=$ General mean of the character understudy.

\section{Phenotypic coefficient of variation (PCV)}

The magnitude of phenotypic variation existing in a character was estimated by the formula given by Burton (1952). 
$\mathrm{PCV}=\frac{\sqrt{V_{\mathrm{p}}}}{\overline{\mathrm{X}}} \mathrm{X} 100$

Where,

$\mathrm{Vp}=$ Phenotypic variance and

$\bar{x}=$ General mean of the character under study.

\section{Heritability [ $h^{2}$ broad sense]}

Heritability in the broad sense refers to the proportion of genotypic variance to the total variance observed in total population. Heritability $\left(\mathrm{h}^{2}\right)$ in broad sense was calculated according to the formula given by Allard (1960).

$h^{2}=v_{g} / v_{p} X 100$

Where,

$\mathrm{h}^{2}=$ Heritability (broad sense)

$\mathrm{Vg}=$ Genotypic variance and

$\mathrm{Vp}=$ Phenotypic variance

\section{Genetic advance (GA)}

This was estimated as per the formula proposed by Johnson et al., (1955).

$\mathrm{GA}=\mathrm{K} \times \mathrm{h}^{2}{ }_{\mathrm{bs}} \times \sigma_{\mathrm{p}}$

Where

$\mathrm{K}=$ Selection differential at $5 \%$ selection intensity which accounts to a constant value 2.06 (Lush, 1949).

$\mathrm{h}^{2}(\mathrm{~b})=$ Heritability in broad sense

$\sigma_{\mathrm{p}}=$ Phenotypic standard deviation

\section{Results and Discussion}

The analysis of variance indicated highly significant differences among the genotypes for all the traits studied (Table. 2). The results revealed that the values of PCV were higher than the GCV values but the difference between PCV and GCV were very low indicating these characters are less influenced by environment.

The study of genetic parameters in 32 cucumber genotypes revealed the presence of large amount of variation (Fig. 1). Maximum amount of variability was recorded for characters viz., total yield per plant (1.67 to $6.49 \mathrm{~kg})$, average fruit weight (203.67 to $1088.13 \mathrm{~g})$, fruit length $(4.74$ to $26.69 \mathrm{~cm})$ presented in Table 2 indicating the scope for selection of suitable initial breeding material for further improvement. The results are in accordance with the reports of Kumar et al., (2011) in cucumber.

The estimates of PCV and GCV were high (> $20 \%$ ) for characters (Table 3) such as number of primary branches per plant $(36.91 \%$, $36.40 \%$ ), node number at which first female flower appears $(36.78 \%, 23.92 \%)$, fruit length $(45.60 \%, 29.23 \%)$, fruit weight $(36.13 \%$, $23.72 \%)$, number of seeds per fruit $(30.06 \%$, $28.32 \%), 100$ seed weight $(42.58 \%, 40.01 \%)$, total soluble solids $(24.64 \%, 23.61 \%)$, carotenoids $(66.91 \%, 62.09 \%)$, acidity (48.84\%, 46.39\%), ascorbic acid (25.16\%, $23.84)$, aphid incidence $(122.11 \%, 119.51 \%)$, powdery mildew incidence $(53.17 \%, 51.83 \%)$ and fruit yield per vine $(38.45 \%, 36.04 \%)$. High PCV and GCV values indicate large amount of variation and consequently more scope for their improvement through selection. The higher the GCV, the more will be the chance for exploitation of that particular character in a selection programme. These findings are in agreement with Veena et al., (2012).

\section{Heritability}

The estimates of heritability (Table 4.10) were high $(>60 \%)$ for vine length $(60.66 \%)$, number of primary branches per plant $(97.2 \%)$, days to first male flowering (89.9\%), days to first female flowering (92.4\%), days to $50 \%$ male flowering $(95.9 \%)$, days to $50 \%$ female flowering $(89.2 \%)$, days to first fruit harvest (95.7\%), days to last fruit harvest $(95.1 \%)$, number of seeds per fruit $(88.8 \%)$, total soluble solids $(91.8 \%)$, carotenoids $(86.1 \%)$, acidity $(90.2 \%)$, ascorbic acid (89.8\%), aphid 
incidence $(95.8 \%)$, powdery mildew incidence $(95.0 \%)$ and fruit yield per vine $(87.8 \%)$. Similar findings were reported by Tomar et al., 2008 in cucumber. As per the above results, it can be concluded that direct selection based on these characters will be promising.

The estimates for genetic advance as percent of mean (Table. 3) were high (>20\%) for number of primary branches per plant $(73.93 \%)$, days to first male flowering (23.67\%), days to first female flowering $(22.34 \%)$, days to $50 \%$ male flowering $(23.22 \%)$, days to $50 \%$ female flowering $(24.07 \%)$, days to first fruit harvest $(22.52 \%)$, days to last fruit harvest (21.12\%), inter nodal length $(21.90 \%)$, node number at which first female flower appears $(32.04 \%)$, fruit length $(38.59 \%)$, fruit diameter $(24.41 \%)$, fruit weight $(32.07 \%)$, number of seeds per fruit (54.97\%), 100 seed weight $(77.44 \%)$, total soluble solids $(46.60 \%)$, carotenoids $(118.69 \%)$, acidity $(90.78 \%)$, ascorbic acid (46.52\%), aphid incidence (240.96\%), powdery mildew incidence $(104.09 \%)$ and fruit yield per vine $(69.57 \%)$. Characters showing high value of GAM indicate the role of additive gene action and hence selection is more effective for such characters. These findings are agreement with Chikezie et al., 2015 in cucumber.

Johnson et al., (1955) reported that high heritability along with high genetic gain was more efficient and dependable in predicting the improvement through selection. Characters like primary branches per plant, days to first male flowering, days to first female flowering, days to $50 \%$ male flowering, days to $50 \%$ female flowering, days to first fruit harvest, days to last harvest, number of seeds per fruit, TSS, carotenoids, acidity, ascorbic acid and fruit yield per vine recorded high heritability accompanied with high genetic advance. Thus, the expression of these traits is predominantly governed by additive gene effects and therefore selection based on phenotypic performance will be useful to improve these characters in future as suggested by Chandrashekhar et al., (2006).

The characters viz., number of primary branches per plant, number of seeds per fruit, carotenoids, TSS, acidity, ascorbic acid and fruit yield were observed with high genetic variability, high heritability in conjunction with high genetic advance as percent mean indicating the predominance of additive gene action on the expression of these traits and hence direct selection will be rewarding for improvement of these traits in cucumber.

\section{Genetic divergence}

The genetic diversity for 32 genotypes of cucumber were assessed quantitatively for yield, yield related attributes, aphid and powdery mildew incidence by employing Mahalonobis $\mathrm{D}^{2}$ statistics. Tocher's method (Rao, 1952) was used to group 32 cucumber genotypes into six clusters by treating estimated $D^{2}$ values as the square of the generalized distance.

The intra and inter cluster $\mathrm{D}^{2}$ values among 6 clusters were presented given in Table 4 . The inter cluster $\mathrm{D}^{2}$ value is the main criterion for selection of genotypes. The genotypes belonging to cluster VI and V (622.52), followed by cluster IV and III (591.45) are genetically more divergent and selection of parents from these diverse clusters for hybridization programme would help in achieving novel recombinants in cucumber.

A wide range of variation was registered in the cluster means for most of the characters studied. Cluster VI ranked first with respect to the desirable characters viz., number of fruits per plant, fruit length fruit diameter and fruit yield per vine. 
Table 1 List of cucumber genotypes along with their sources

\begin{tabular}{|c|c|c|c|}
\hline S. No & Genotypes & Accession No & Source/Place \\
\hline 1. & A1 & SKY 613476 & NBPGR, Thrissur, Kerala \\
\hline 2. & A2 & SKY 613477 & NBPGR, Thrissur, Kerala \\
\hline 3. & A3 & SKY 613479 & NBPGR, Thrissur, Kerala \\
\hline 4. & A4 & SKY 613480 & NBPGR, Thrissur, Kerala \\
\hline 5. & A5 & SKY 613481 & NBPGR, Thrissur, Kerala \\
\hline 6. & A6 & SKY 613484 & NBPGR, Thrissur, Kerala \\
\hline 7. & A7 & SKY 613485 & NBPGR, Thrissur, Kerala \\
\hline 8. & A8 & KP613474 & NBPGR, Thrissur, Kerala \\
\hline 9. & A9 & JJK 595518 & NBPGR, Thrissur, Kerala \\
\hline 10. & A10 & JS541367 & NBPGR, Thrissur, Kerala \\
\hline 11. & A11 & JR469517 & NBPGR, Thrissur, Kerala \\
\hline 12. & A12 & JB595504 & NBPGR, Thrissur, Kerala \\
\hline 13. & A13 & JB613462 & NBPGR, Thrissur, Kerala \\
\hline 14. & A14 & JB613488 & NBPGR, Thrissur, Kerala \\
\hline 15. & A15 & JB595508A & NBPGR, Thrissur, Kerala \\
\hline 16. & A16 & JB613470 & NBPGR, Thrissur, Kerala \\
\hline 17. & A17 & JB595510 & NBPGR, Thrissur, Kerala \\
\hline 18. & A18 & JB618083 & NBPGR, Thrissur, Kerala \\
\hline 19. & A19 & JB595512 & NBPGR, Thrissur, Kerala \\
\hline 20. & A20 & JB 618084 & NBPGR, Thrissur, Kerala \\
\hline 21. & A21 & IC 567558-2 & NBPGR, Jodhpur, Rajasthan \\
\hline 22. & A22 & IC 321367 & NBPGR, Jodhpur, Rajasthan \\
\hline 23. & A23 & IC $567558-3$ & NBPGR, Jodhpur, Rajasthan \\
\hline 24. & A24 & IC 321370 & NBPGR, Jodhpur, Rajasthan \\
\hline 25. & A25 & IC 567558-4 & NBPGR, Jodhpur, Rajasthan \\
\hline 26. & A26 & IC 321375 & NBPGR, Jodhpur, Rajasthan \\
\hline 27. & A27 & IC 567558-1 & NBPGR, Jodhpur, Rajasthan \\
\hline 28. & A28 & IC $567558-5$ & NBPGR, Jodhpur, Rajasthan \\
\hline 29. & A29 & IC 321379 & NBPGR, Jodhpur, Rajasthan \\
\hline 30. & A30 & IC 550207 & NBPGR, Jodhpur, Rajasthan \\
\hline 31. & A31 & ICPCHI & F1 Hybrid \\
\hline 32. & A32 & $\begin{array}{l}\text { Multistar RZ } \\
\text { F1 }\end{array}$ & RijkZwaan \\
\hline
\end{tabular}


Table.2 Analysis of variance for various horticultural traits in cucumber

\begin{tabular}{|c|c|c|c|c|c|c|}
\hline & \multicolumn{6}{|c|}{ Source of variance } \\
\hline $\begin{array}{l}\text { S. } \\
\text { No }\end{array}$ & Parameters & & Genotypes & $\begin{array}{c}\text { Replicatio } \\
\text { ns }\end{array}$ & Errors & Total \\
\hline & & df & 31 & 2 & 62 & 95 \\
\hline 1. & Vine Length $(\mathrm{cm})$ & & $63.54 * *$ & 5.61 & 21.38 & 90.53 \\
\hline 2. & $\begin{array}{l}\text { Number of primary } \\
\text { branches per plant }\end{array}$ & & $6.60 * *$ & 0.00 & 0.06 & 6.67 \\
\hline 3. & Inter nodal length $(\mathrm{cm})$ & & $21.52^{* *}$ & 0.23 & 4.84 & 26.59 \\
\hline 4. & Number of nodes per vine & & $6.81 * *$ & $2.21 *$ & 1.76 & 10.78 \\
\hline 5. & $\begin{array}{l}\text { Node number at which first } \\
\text { female flower appears }\end{array}$ & & $13.68^{* *}$ & 0.32 & 4.28 & 18.28 \\
\hline 6. & Days to first male flowering & & $108.13^{* *}$ & 1.61 & 3.90 & 113.63 \\
\hline 7. & $\begin{array}{l}\text { Days to first female } \\
\text { flowering }\end{array}$ & & $110.49 * *$ & 7.53 & 2.94 & 120.95 \\
\hline 8. & $\begin{array}{l}\text { Days to } 50 \% \text { male } \\
\text { flowering }\end{array}$ & & $103.92 * *$ & 0.15 & 1.45 & 105.52 \\
\hline 9. & $\begin{array}{l}\text { Days to } 50 \% \\
\text { female flowering }\end{array}$ & & $110.47 * *$ & 11.83 & 4.30 & 126.59 \\
\hline 10. & Days to first fruit harvest & & $164.12 * *$ & 0.64 & 2.39 & 167.15 \\
\hline 11. & Days to last fruit harvest & & $212.08 * *$ & 0.01 & 3.57 & 215.66 \\
\hline 12. & Number of fruits per plant & & $1.39 * *$ & 0.08 & 0.42 & 1.89 \\
\hline 13. & Fruit length $(\mathrm{cm})$ & & $128.33 * *$ & $2.19^{*}$ & 41.51 & 172.03 \\
\hline 14. & Fruit diameter $(\mathrm{cm})$ & & $6.12 * *$ & $1.22^{*}$ & 1.64 & 8.98 \\
\hline 15. & Fruit weight (gm) & & $\begin{array}{l}92588.98 \\
* *\end{array}$ & $\begin{array}{l}10179.93 \\
* *\end{array}$ & $\begin{array}{l}28302.4 \\
0\end{array}$ & $\begin{array}{l}131071 . \\
3\end{array}$ \\
\hline 16. & Number of seeds per fruit & & $\begin{array}{l}17336.29 \\
* *\end{array}$ & $407.19 * *$ & 700.82 & $\begin{array}{l}18444.3 \\
0\end{array}$ \\
\hline 17. & 100 Seed weight $(\mathrm{gm})$ & & $1.84 * *$ & 0.05 & 0.08 & 1.97 \\
\hline 18. & TSS $\left({ }^{0}\right.$ Brix $)$ & & $1.49 * *$ & 0.01 & 0.04 & 1.54 \\
\hline 19. & Carotenoids $(\mu \mathrm{g} / 100 \mathrm{gm})$ & & $0.02 * *$ & 0.00 & 0.00 & 0.03 \\
\hline 20. & Acidity $(\%)$ & & $0.07 * *$ & 0.01 & 0.00 & 0.08 \\
\hline 21. & $\begin{array}{l}\text { Ascorbic Acid (mg/100 gm } \\
\text { fresh fruit weight) }\end{array}$ & & $1.54 * *$ & 0.00 & 0.06 & 1.60 \\
\hline 22. & Aphids incidence & & $1273.6^{* *}$ & 47.58 & 183.06 & 1297.3 \\
\hline 23. & Powdery mildew incidence & & $\begin{array}{l}2112.00^{*} \\
*\end{array}$ & 4.63 & 36.11 & 2152.73 \\
\hline 24. & Fruit yield (kg/vine) & & $4.22 * *$ & 0.17 & 0.19 & 4.57 \\
\hline
\end{tabular}


Table.3 Estimates of variability, heritability and genetic advance as percent of mean for 24 characters in cucumber

\begin{tabular}{|c|c|c|c|c|c|c|c|c|c|}
\hline \multirow[b]{2}{*}{$\begin{array}{l}\text { S. } \\
\text { No }\end{array}$} & \multirow[b]{2}{*}{ Parameters } & \multirow[b]{2}{*}{$\begin{array}{l}\text { General } \\
\text { Mean }\end{array}$} & \multicolumn{2}{|c|}{ Variance } & \multicolumn{2}{|c|}{ Coefficient of variation } & \multirow[b]{2}{*}{$\begin{array}{c}\text { Heritability } \\
\text { (Broad sense } \\
\%)\end{array}$} & \multirow[b]{2}{*}{$\begin{array}{l}\text { Genetic } \\
\text { advance } \\
@ 5 \%\end{array}$} & \multirow[b]{2}{*}{$\begin{array}{l}\text { GAM } \\
\text { @ 5\% }\end{array}$} \\
\hline & & & $\begin{array}{l}\text { Genotypic } \\
\text { (rg) }\end{array}$ & $\begin{array}{l}\text { Phenotypic } \\
\text { (rp) }\end{array}$ & $\begin{array}{c}\text { Genotypic } \\
\%\end{array}$ & $\begin{array}{c}\text { Phenotypic } \\
\%\end{array}$ & & & \\
\hline 1 & Vine Length $(\mathrm{cm})$ & 214.45 & 58.5 & 64.5 & 6.35 & 5.15 & 60.66 & 26.5 & 12.35 \\
\hline 3 & Inter nodal length $(\mathrm{cm})$ & 16.21 & 5.56 & 10.40 & 14.54 & 19.89 & 53.5 & 3.55 & 21.90 \\
\hline 4 & Number of nodes per vine & 12.79 & 1.68 & 3.44 & 10.14 & 14.51 & 48.8 & 1.87 & 14.59 \\
\hline 5 & $\begin{array}{l}\text { Node no. at which first female flower } \\
\text { appears }\end{array}$ & 7.40 & 3.14 & 7.41 & 23.92 & 36.78 & 42.3 & 2.37 & 32.04 \\
\hline 6 & Days to first male flowering & 48.64 & 34.74 & 38.64 & 12.12 & 12.78 & 89.9 & 11.51 & 23.67 \\
\hline 7 & Days to first female flowering & 53.08 & 35.85 & 38.79 & 11.28 & 11.73 & 92.4 & 11.86 & 22.34 \\
\hline 8 & Days to $50 \%$ male flowering & 50.77 & 34.15 & 35.61 & 11.51 & 11.75 & 95.9 & 11.79 & 23.22 \\
\hline 9 & Days to $50 \%$ female flowering & 48.08 & 35.39 & 39.69 & 12.37 & 13.10 & 89.2 & 11.57 & 24.07 \\
\hline 10 & Days to first fruit harvest & 65.71 & 53.91 & 56.30 & 11.17 & 11.42 & 95.7 & 14.80 & 22.52 \\
\hline 11 & Days to last fruit harvest & 79.32 & 69.50 & 73.07 & 10.51 & 10.78 & 95.1 & 16.75 & 21.12 \\
\hline 12 & Number of fruits per plant & 5.12 & 0.32 & 0.75 & 11.12 & 16.85 & 43.5 & 0.77 & 15.11 \\
\hline 13 & Fruit length $(\mathrm{cm})$ & 18.41 & 28.94 & 70.45 & 29.23 & 45.60 & 41.1 & 7.10 & 38.59 \\
\hline 15 & Fruit weight (gm) & 617.20 & 21428.86 & 49731.26 & 23.72 & 36.13 & 43.1 & 197.95 & 32.07 \\
\hline 16 & Number of seeds per fruit & 262.96 & 5545.16 & 6245.98 & 28.32 & 30.06 & 88.8 & 144.54 & 54.97 \\
\hline 17 & 100 Seed weight $(\mathrm{gm})$ & 1.92 & 0.59 & 0.67 & 40.01 & 42.58 & 88.3 & 1.48 & 77.44 \\
\hline 18 & TSS (0Brix) & 2.94 & 0.48 & 0.52 & 23.61 & 24.64 & 91.8 & 1.37 & 46.60 \\
\hline 19 & Carotenoids micro gm/100 gm & 0.14 & 0.01 & 0.01 & 62.09 & 66.91 & 86.1 & 0.17 & 118.69 \\
\hline 20 & Acidity (\%) & 0.33 & 0.02 & 0.03 & 46.39 & 48.84 & 90.2 & 0.30 & 90.78 \\
\hline 21 & $\begin{array}{l}\begin{array}{l}\text { Ascorbic Acid }(\mathrm{mg} / 100 \mathrm{gm} \text { fresh fruit } \\
\text { weigh) }\end{array}\end{array}$ & 2.95 & 0.49 & 0.55 & 23.84 & 25.16 & 89.8 & 1.37 & 46.52 \\
\hline 22 & Aphids incidence & 541.30 & 418500.84 & 436873.91 & 119.51 & 122.11 & 95.8 & 1304.32 & 240.96 \\
\hline 23 & Powdery mildew incidence & 50.75 & 691.96 & 728.07 & 51.83 & 53.17 & 95.0 & 52.83 & 104.09 \\
\hline 24 & Fruit yield (kg/vine) & 3.22 & 1.34 & 1.53 & 36.04 & 38.45 & 87.8 & 2.24 & 69.57 \\
\hline
\end{tabular}


Table.4 Average intra and inter cluster D2 values of cucumber genotypes

\begin{tabular}{|c|c|c|c|c|c|c|}
\hline Cluster & I & II & III & IV & V & VI \\
\hline I & $\begin{array}{l}88.25 \\
(9.39)\end{array}$ & $\begin{array}{l}196.98 \\
(14.03)\end{array}$ & $\begin{array}{l}454.74 \\
(21.32)\end{array}$ & $\begin{array}{l}187.69 \\
(13.70)\end{array}$ & $\begin{array}{l}452.50 \\
(21.27)\end{array}$ & $\begin{array}{l}517.70 \\
(22.75)\end{array}$ \\
\hline II & & $\begin{array}{l}125.73 \\
(11.21)\end{array}$ & $\begin{array}{l}258.77 \\
(16.09)\end{array}$ & $\begin{array}{l}289.84 \\
(17.02)\end{array}$ & $\begin{array}{l}298.35 \\
(17.27)\end{array}$ & $\begin{array}{l}404.27 \\
(20.11)\end{array}$ \\
\hline III & & & $\begin{array}{l}60.34 \\
(7.77)\end{array}$ & $\begin{array}{l}591.45 \\
(24.32)\end{array}$ & $\begin{array}{l}518.64 \\
(22.77)\end{array}$ & $\begin{array}{l}415.66 \\
(20.39)\end{array}$ \\
\hline IV & & & & $\begin{array}{l}180.69 \\
(13.44)\end{array}$ & $\begin{array}{l}507.42 \\
(22.53)\end{array}$ & $\begin{array}{l}453.65 \\
(21.30)\end{array}$ \\
\hline V & & & & & $\begin{array}{l}0.00 \\
(0.00)\end{array}$ & $\begin{array}{l}622.52 \\
(24.95)\end{array}$ \\
\hline VI & & & & & & $\begin{array}{l}\mathbf{0 . 0 0} \\
(\mathbf{0 . 0 0})\end{array}$ \\
\hline
\end{tabular}

Fig.1 Phenotypic and genotypic coefficient of variation, Heritability, genetic advance for different characters in cucumber

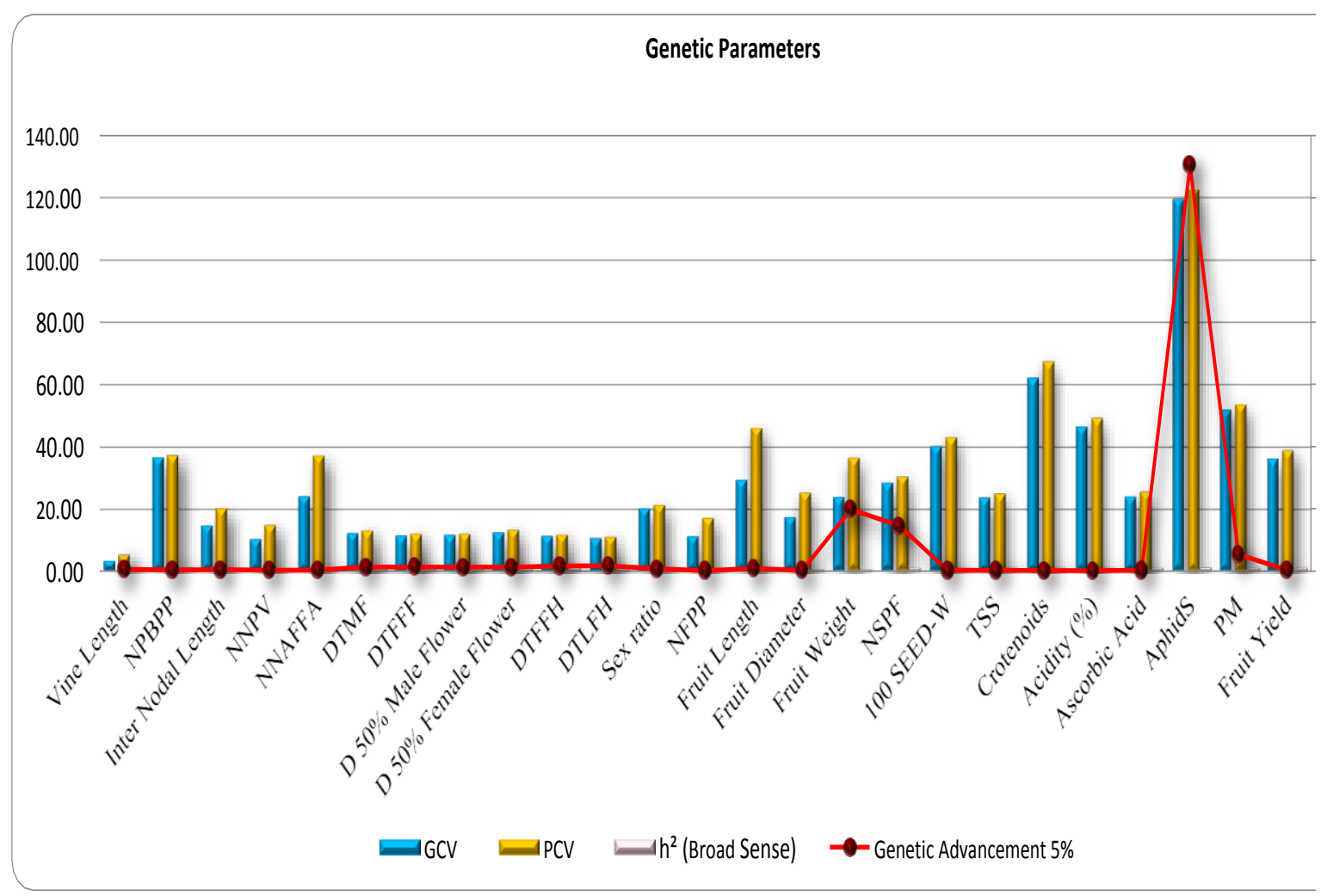


The same cluster also recorded lower mean value for powdery mildew incidence. Cluster III ranked first for earliness characters like days to first female flowering, days to $50 \%$ female flowering and days to first fruit harvest, besides having ideal quality characters like maximum cluster mean value for carotenoids. Hence genotypes belonging to the clusters VI and III are amenable for exploitation in future crop improvement of cucumber.

In conclusion, cucumber genotypes exhibited high variability for most of the traits like plant growth characters, fruit characters, quality and seed characters. On the basis of mean performance of the genotypes studied, in terms of earliness, yield and quality traits, the genotypes viz., A10 (JS 541367), A12 (JB 595504), A22 (IC 321367) and A30 (IC 550207) were found superior and were identified as promising lines for further crop improvement in cucumber. These genotypes belong to the clusters VI and III which are genetically divergent and hybridization between these genotypes will likely produce desirable segregants.

\section{Acknowledgment}

Authors are thankful to the administrative team and all the supporting staff involved in the present research especially thanks to Dr. YSR Horticultural University.

\section{References}

Al-Jibouri, H.A., Miller, P.A., Robinson, H.F.1958.Genotypic and environmental variance and covariance in upland cotton crosses of inter specific origin, Agron J. 50:633637.

Bailey, L.H. 1969. Manual of Cultivated Plants. Macmillan Company, New York.
Burton, G.W and Devane, E.H. 1953 Estimating heritability in tall fescue (Festuca arundinaceae) from replicated clonal material. Agronomy Journal. 45: 478-481.

Bhawana, B., Singh, M.P., Srivastava, B.K., Singh, Y.V. and Singh, P.K. 2010.Evaluation of open-pollinated varieties and hybrids of cucumber for off season production under naturally ventilated polyhouse. Indian $J$. Hort.67(2):202-205.

Chandrashekhar, N. and Hanchinamani, N. 2006. Genetic variability, divergence, heterosis and combining ability studies in cucumber (Cucumis sativus L.).Ph.D. Thesis, UAS, Dharwad, Karnataka, India.

Chikezie, O.E., Peter, E.O., Christian, U.A., and Uche, P.C. 2016. Studies ofphenotypic and genotypic variation in sixteen cucumber genotypes. Chilean Journal of Agricultural Research. 76(3): 307-313.

Faruk, H., Rabbani, M.G., Hakim, M.A., Amanullah, A.S.M. and Ahsanullah, A.S.M. 2010. Study on variability character association and yield performance of Cucumber (Cucumis sativus L.). Bangladesh Research Publications Journal. 4(3):297-311.

Gaikwad, A.G., Dhumal, S.S., Sonawane, H.G. and Musmade, A.M. 2011. Genetic divergence in cucumber (Cucumis sativus L.). The Asian Journal of Horticulture. 6(1):148-150.

Johnson, H.W., Robinson, J.F., Comstock, R.E.1955. Estimation of genetic and environmental variability in soybean. Agron. J. 7:314-318.

Kumar, S., Kumar, R., Gupta, R.K, Sepahia, R. 2011. Studies on correlation and path coefficient analysis for yield and its contributing traits in cucumber. Crop Improv. 38(1): 18-23.

Panse, V.G. and Sukhatme, P.V. 1961. 
Statistical methods for agricultural workers2 ${ }^{\text {nd }}$ Ed., ICAR, New Delhi: p.359.

Lush, J.L. 1949. Heritability characters in farm animals. Proceedings of $8^{\text {th }}$ International Congress genetics. Heriditas. 35: 356-375.

Rao, C.R. 1952. Advanced statistical Methods in Biometrical Research. Jhon Wiley and Sons. New York. pp. 45-110.

Rastogi, K.B. 1998. Cucumber hybrid production. Breeding and Seed Production. CAS Horticulture, (Veg.), pp.76-80.

Sebastian P.M, Schaefer H, Telford I.R.H. and Renner S.S. 2010. Cucumber and melon have their wild progenitors in India, and the sister species of Cucumis melo is from Australia.
Proceedings of the National Academy of Sciences, USA. 107:14269-14273.

Simmonds, N.M. 1962. Variability in crop plants its use and conservation. Botanical Review, 37: 422-465.

Singh, R.K and Chaudhury, B.D. 1985. Biometrical methods in quantitative genetics analysis 3rd Ed. Kalyani Publishers New Delhi: 53-54.

Tomar, R. S., Kulkarni, G. U. and Kakade, D. K. 2008. Genetic analysis in muskmelon (Cucumis melo L.). J. Hortic. Sci. 3(2): 112-118.

Veena, R., Amrik, S.S., Pitchaimuthu, M. and Souravi, K. 2012. Geneticevaluation of Cucumber (Cucumis sativus L.) genotypes for some yield and related traits. Electronic Journal of Plant Breeding. 3(3): 945-948.

\section{How to cite this article:}

Phani Kumar, J, Sadarunnisa Syed, P. Syam Sundar Reddy, L. Mukunda Lakshmi and Srinivasa Reddy, D. 2018. Genetic Divergence Studies in Cucumber (Cucumis sativus L.) Genotypes for Yield and Quality Int.J.Curr.Microbiol.App.Sci. 7(12): 2633-2643. doi: https://doi.org/10.20546/ijcmas.2018.712.299 